\title{
TIPPING THE SCALES: A LIBRA'S DILEMMA
}

Terry-Anne Selekow

Moira De Groot

Laura Dison

Michelle Friedman

The focus of this article is on teaching language and learning skills within subjectspecific disciplines at a tertiary institution. Using concrete examples drawn from their everyday teaching experiences, the authors highlight the constraints of developing appropriately sequenced language and learning materials within a predetermined and content-driven curriculum. Although the authors agree that learning and language competencies should be taught within specific contexts, they argue that in order to teach these skills effectively, there needs to be a closer collaboration between those working within the disciplines and the language and learning specialists.

Die fokus van hierdie artikel is op taalonderwys en leervaardighede binne vakspesifieke dissiplines aan 'n tersiêre inrigting. Die skrywers gebruik konkrete voorbeelde vanuit hul eie onderrigondervindings om op die beperkinge te wys wat aan die ontwikkeling van sinvol-geordende taal- en leermateriaal binne 'n voorafbepaalde en inhoudgedrewe kurrikulum gekoppel is. Alhoewel die skrywers dit eens is dat leer-en taalvaardighede binne bepaalde kontekste onderrig behoort te word, is hulle van mening dat daar nouer samewerking behoort te wees tussen die mense wat binne die betrokke dissiplines werk en die taal- en leerspesialiste om die onderrig van hierdie vaardighede effektief te kan wees in.

\section{INTRODUCTION}

The title of the article makes reference to scales and starsigns, a very unlikely topic of interest for serious teachers and academics. However, the image refers to the delicate balance that needs to be achieved between language and learning skills on the one hand and subject specific or disciplinary content on the other. In this context, the Libran is the Academic Development Programme (ADP) tutor whose job description is to use predetermined discipline-specific content to develop language and learning skills in English second language students. The Libran is thus faced with a tension between "covering the content" and teaching the requisite skills. 
In this article, the authors argue that the curriculum, as it is currently structured, imposes serious constraints on the ADP tutor's capacity to develop language and learning competencies in students. It is argued that the way the curriculum is conceptualised and implemented tips the scales heavily in favour of disciplinary content and that this is often to the detriment of language and learning skills. Hence survival or crisis materials are developed rather than learning materials which are "scaffolded" and developmental. To illustrate this problem, concrete examples are drawn from two disciplines, Psychology and History, within the Arts Faculty at the University of the Witwatersrand.

\section{HISTORY OF CONTEXTUALISED MATERIALS}

The admission of previously excluded students and the changes in student demography present a particular set of challenges to university teachers. Previously, issues such as students' English language competencies and academic preparation for tertiary level study could be taken for granted. Today, these very issues have become central concerns at most universities. The present challenge involves finding a balance between teaching language and related academic skills, while simultaneously covering discipline-specific content.

The University of the Witwatersrand has followed a world-wide trend away from general, decontextualised study skills and language support classes to interventions which are located within various disciplines (Starfield 1990). Many researchers and teachers of study skills have come to the conclusion that students' language and other skills development have to be dealt with within specific contexts because the content and the language of a subject, "the processes or modes of analysis and argument appropriate to the subject", are totally inseparable (Nightingale 1988: 81).

Although the trend is to locate language and learning skills within a specific disciplinary context, Wesche (1992), with particular reference to language programmes in North America, notes that there are a variety of "discipline-based" language teaching models. According to Wesche's typology, the approach adopted by the Arts Faculty fits into the "content-based model" or discipline-based language teaching approach. This is distinguished by "... the concurrent learning of a specific content and related language use skills in a 'content-driven' curriculum. i.e. with the selection and sequencing of language elements determined by the content" (Wesche 1992: 57).

\section{ANALYSIS OF CONTEXTUALISED ACADEMIC DEVELOPMENT MATERIALS}

In both the Psychology and History departments at the University of the Witwatersrand, the content of the discipline is generally covered in lectures. In addition to lectures, students attend a "mainstream" tutorial on a weekly basis. These tutorials are aimed at 
allowing students the opportunity to discuss and evaluate the course material presented in readings and lectures. Competence in English language skills as well as in academic skills is often taken as a given in the design of the tutorial activities. In addition to mainstream tutorials, $\mathrm{AD}$ tutorials are also offered. These tutorials are intended to develop the language and learning abilities through the medium of the course content. The ADP tutors who conduct the departmentally-based tutorials are subject specialists who are also experienced in developing students' language and learning competencies in consultation with the $\mathrm{AD}$ materials writer.

Ideally, as Wesche (1994) points out, by using the content-based model, students are getting "two for one" - they are gaining in the area of content knowledge and, at the same time, are able to develop their communicative competencies. Although in theory this may be the case, experience has led us to question whether this is indeed happening.

To some extent, ADP subject tutors may be involved in curriculum design such as in the design of tasks and tutorial questions for the reading/course packs, but ultimately, the selection of course content remains the domain of the "subject specialists", the lecturers. Much of the work done by ADP tutors, both in the mainstream and in the ADP, revolves around content and academic tasks which have been devised elsewhere. As Hartman and Warren point out, "...the priorities of $\mathrm{AD}$ work in this area (course and curriculum design) are determined by faculty and departmental needs and constraints"(Hartman and Warren, 1994: 253) and this severely limits the effectiveness of $\mathrm{AD}$ work and materials.

Although $\mathrm{AD}$ materials have proved to be a useful and valuable learning resource for students, they are limited in terms of their effectiveness, primarily because of the context in which they, are used. There are a number of reasons for this. Firstly, skills cannot be developed in any systematic way if the content covered in a particular week is not conducive to teaching a particular skill. In essence, if the curriculum is not "scaffolded", it means that skills development cannot take place in a developmental and sequential way. Angelo (1993) says that the weaker a student's learning foundation is, the stronger and more extensive the instructional support that will be required. As the student develops his or her language competencies, the scaffolding can gradually be withdrawn, the aim being for the student to become a "stand-alone" or independent learner.

In addition to the problem of the lack of scaffolding, the large volume of complex content covered in a short period of time in many departments inhibits skills development. Because the syllabuses are content-driven, students may not see the relevance of explicit skills teaching and want to focus on content. Consequently, even if the aim of a particular tutorial is to develop students' reading skills, much of the tutorial may be spent discussing content-related issues which students raise and which cannot be ignored if the tutorial is to be seen by students as relevant and helpful.

Furthermore, the skills developed in $\mathrm{AD}$ tend to be lower order skills, such as finding information and understanding course content, although, as we will illustrate, the tasks students are required to complete are generally higher order tasks. Drawing on Bloom's 
early work on a hierarchical taxonomy of cognitive skills development ( Krathwohl et al., 1956), we work on the premise that the development of higher order skills such as application and evaluation of material cannot be achieved uniess students have had the opportunity to "come to grips" with and understand the issues and debates at hand.

A concrete example drawn from an introductory course in Developmental Psychology best highlights the limitations of working within a predetermined course.

The example reveals the disjuncture between materials developed for mainstream tutorials and those developed for ADP tutorials. Not only does such an analysis reveal the great divide between the lecturer's assumptions about the level of students' knowledge and the students' actual abilities, but it also reflects the constraints that the $\mathrm{AD}$ tutor faces in developing students' knowledge along a developmental sequence from lower order skills to higher order skills. When students attended the AD tutorial, lectures had already covered the theories of Freud, Erikson and Piaget, and students had been instructed to read on these theories. The stated task for the mainstream tutorial involved the tutor reading aloud a case history of "Jane W" and then instructing the students to:

1) discuss how each of the above mentioned psychologists (i.e. Freud, Erikson, Piaget) might understand Jane's response to the situation

2) evaluate the stage theories of Freud, Erikson and Piaget.

If one deconstructs this task to determine precisely what the activities are that the students are expected to engage in, one finds that students are required to:

a) apply knowledge gained from readings/lectures to an unfamiliar situation

b) integrate concepts, terminology, and theory

c) evaluate - take a critical position

d) compare and contrast the different theories in terms of their explanatory power.

It is clear that there are a number of assumptions underlying the lecturer's expectations. If we analyse these expectations, we find that the above tasks assume that students have already

1) experienced this transfer of knowledge (i.e. they have gained the knowledge from lectures, text book and other readings.)

2) understood this content

3) integrated this content.

Such activities, however, call for the use of higher level metacognitive skills which many students do not have. Thus it becomes the task of the $\mathrm{AD}$ tutor to develop them. Yet an analysis of the materials used in ADP tutorials reveals that these objectives are often beyond the scope of the $\mathrm{AD}$ tutorial. 
Instead of, as envisaged, devoting $\mathrm{AD}$ tutorials to the development of higher order skills, it was necessary to develop activities which could help students cope with typical mainstream tasks.

Although lectures had covered the main concepts and ideas, it soon became apparent that students were hopelessly confused. All the newly introduced concepts were seemingly "swimming" around in students' heads. It was clear that it would be necessary to go back to lecture materials and devise an activity which would allow students to understand the material which had been covered in lectures before students could attempt the mainstream tutorial activity.

We hoped that the materials developed for the AD tutorial (a grid for students to organise information in a systematic way), would enable students to find the information, understand it, and compile a page of meaningful notes. However, we had not moved even one step in the direction of applying the new concepts to a real life situation or evaluating these concepts.

The situation for History I is similar: AD development is inhibited by the mainstream context in which it operates. Similarly, the lack of scaffolding (support and structure) within the mainstream curriculum makes it impossible to sequence tasks within the $\mathrm{AD}$ tutorials; rather the focus in the first AD tutorial is on higher order tasks completely inappropriate to the students' conceptual ability at this stage of the year. The following example highlights these problems.

The set task for first year History students was to write a one to two page essay on the fairly complex matter of the origins of the migrant labour system:

Account for the development of the migrant labour system in Central Africa.

All History 1 students were given two readings on migrant labour: the one by Stichter emphasised an Africanist explanation on the origins of the migrant labour system, the other by Vail provided a Marxist interpretation which emphasised an explanation which was functional to capitalism. As this was the students' first written assignment, considerable guidance was given to all first year students in the form of a worksheet, which was drawn up by the AD tutor. This in itself was an innovation, the mainstream staff initially being reluctant to provide mainstream students with such a structured form of guidance. Students were given a set of directed questions which guided them towards the different approaches adopted by each historian. A further set of instructions was given to students to assist them with structuring an argument in answering the question.

In setting the assignment for the mainstream tutorial, the lecturer of the course clearly assumed that the reading and understanding of these fairly complex articles would not be a problem for students, and that students would be able to identify each historian's line of argument clearly. 
The AD tutor could not make such assumptions. This was the first reading and writing exercise for students entering the academic environment of the History department. Prior to this, students who had studied History at school had focused on single cause explanations, a clear list of facts that could be learnt by rote for success in exams, and importantly, a single textbook which offered these facts for study.

The first AD tutorial of the year intended to surmount some of these problems. The aims of this tutorial were manifold: First, it provided a reading exercise. This was the students' first introduction to an academic article. Secondly, it introduced students to the structure of an argument as presented by a certain historian. The article by Stichter lent itself particularly well to this approach. It was clearly structured, with a coherent and developed line of argument. AD students were encouraged to look for language indicators which would highlight the progression of the historian's argument. Further, students were encouraged to use similar indicators in the construction of their own argument.

Ideally one would have liked to have done a pre-reading exercise with students as a first tutorial, with the emphasis on skimming and scanning, but because the assignment was due by the next week, this was not possible. The constraints of the mainstream programme directly impinged on the nature of the work covered in AD tutorials and the nature of the materials developed. A developmental approach to reading skills had to be abandoned in order to concentrate on argument construction, a skill that was essential for the writing of the mainstream task. The construction of an argument is essentially a higher order skill and should not have been introduced at so early a stage in the year's programme. This is a particularly effective example of how $\mathrm{AD}$ in history is constrained and to some extent hamstrung by the design of the mainstream course.

The AD tutor in History, therefore, faces similar problems to those of the AD tutor in Psychology. Many of the materials developed for AD in History are based on survival skills, and an integrated and developmental approach is not achieved. A further problem is that the skills discussed in a particular tutorial cannot be refined in the subsequent meetings. Each week brings with it the need to equip students with further skills to meet yet another difficult task.

Thus, AD does not satisfactorily move students along a developmental sequence of skills acquisition. Because new material is introduced so rapidly, tutors do not have the time to move from the fundamental skills of finding and understanding information to the higher level skills of applying and evaluating. The implication of this for underprepared students is that they are unlikely to develop these higher level skills.

\section{CONCLUSION}

Although the focus in this paper has been on the integration of language and learning skills within the context of a tertiary institution, this issue has broader implications and is 
also relevant to secondary (and primary) schools. Curriculum designers need to give explicit attention to language and learning objectives as well as content.. This should be done in such a way that both content and skills are sequenced and scaffolded. This implies starting with the "simple" and working up to the more complex. Of course this is not as straightforward as it may sound and as Celce-Murcia (1991: 291) points out: "What constitutes simplicity and complexity has not ever been operationally defined with any success...". However, research on learning taxonomies and scaffolding has suggested that higher order skills cannot be developed if prerequisite lower order strategies have not been mastered. Thus developmental sequencing, not only in terms of content, but also in terms of skills, needs to be carefully planned and implemented.

Research has also illustrated that, for transfer to occur, learning processes need to be made explicit and that if the focus is on covering huge volumes of content to the detriment of metacognitive processing, then very is likely to be achieved in terms of developing language and learning skills.

If content is given primacy/prominence, then students may "lose both ways". Not only will learning and language skills be sacrificed, but students may also not develop the requisite skills to master and comprehend the content.

The real challenge lies in translating philosophical and theoretical views of language and learning into effective practice. What is thus needed is a pedagogic framework for integrating theory and practice. In this regard, Dubin and Olshtain (1986: 40) draw a useful distinction between curriculum and syllabus.

A curriculum deals with abstract, general goals, while a syllabus, or the instructional plans, guide teachers and learners in everyday concerns. In fact, a chief task for course designers is to turn abstract curriculum goals into concrete objectives in the syllabus.

It is our contention that these objectives need to be framed not only in terms of "what content should we teach" but also in terms of "what skills and processes should we teach and in what order". We are not arguing that content should be secondary, as the specific disciplinary genre is crucial, but we are saying that the history of teaching at.tertiary institutions has tended to dichotomise skills and content (skills are taught in $\mathrm{AD}$ while content is the domain of lecturers), and there is an urgent need to follow a more integrated approach.

In order for this to happen, we need to think about the most effective way for AD tutors to work with lecturers to develop an integrated curriculum that will ensure that the scales are not tilted either way.

\section{REFERENCES}


ANGELO, TA. 1993. A teachers dozen. AAHE Bulletin.

CELCE-MURCIA, M. 1991. Teaching English as a second language (2nd edition) Boston: Heinle and Heinle Publishers.

DUBIN, F. AND E. OLSHTAIN. 1986. How goals become realized through instructional plans in Course Design. Cambridge, Cambridge University Press.

KRATHWOHL, DR, BS BLOOM AND BB MASH 1956. Taxonomy of educational objectives: the classification of educational goals. New York:

KRUEGER, M and RF MCKAY (Eds). 1994. Language and content: discipline and content-based approaches to language study. Lexington: D.C. Heath and Company.

NIGHTINGALE, P. 1988. Language and learning: a bibliographical essay. In Taylor G. et al (Eds) Literacy by degrees. Milton Keynes: The Society for Research into Higher Education and Open University Press.

STARFIELD, S. 1990. Science and language: a new look at some old issues. South African Journal of Higher Education, 4(2): 34-39

WESCHE, MB. 1994. Discipline-based approaches to language study: research issues and outcomes. In Krueger, M and Ryan, F. (Eds) Language and content: discipline and content-based approaches to language study. Lexington: DC Heath and Company. 